\title{
Calcium Nitrate Priming Increases the Germination Rate of Eggplant Seeds
}

\author{
Josiane S. Salles ${ }^{1}$, Alexandre H. F. de Lima ${ }^{1}$, Flávio F. da S. Binotti ${ }^{1}$, Edilson Costa ${ }^{1}$, Eliana D. C. Binotti ${ }^{1}$, \\ Jussara S. Salles ${ }^{1}$, Gustavo H. da C. Vieira ${ }^{1} \&$ Andreia F. G. O. de Souza ${ }^{1}$ \\ ${ }^{1}$ Department of agronomy, State University of Mato Grosso do Sul, Cassilândia, MS, Brazil \\ Correspondence: Josiane S. Salles, Department of agronomy and vegetable ambiance, State University of \\ Mato Grosso do Sul, Cassilândia, MS, Brazil. Tel: 55-679-8159-2907. E-mail: josi_souzasalles@hotmail.com
}

$\begin{array}{lc}\text { Received: May 15, } 2019 & \text { Accepted: July 14, } 2019 \quad \text { Online Published: September 15, } 2019 \\ \text { doi:10.5539/jas.v11n15p181 } & \text { URL: https://doi.org/10.5539/jas.v11n15p181 }\end{array}$

The research is financed by Capes, CNPq, and Fundect.

\begin{abstract}
The priming may promote greater expression of the physiological potential of the seeds and contribute to the germination process under adverse environmental conditions. The objective of this study was to evaluate the physiological potential of eggplant seeds primed with different chemical agents and exposed to adverse temperatures. Seeds were subjected to priming with five chemical agents [unprimed (control); water (hydropriming); calcium nitrate $(0.2 \%)$; amino acid L-phenylalanine $(0.05 \%)$; L-phenylalanine $(0.05 \%)+$ calcium nitrate $(0.2 \%)$ ] and at temperatures of $15,25,35$ and $41{ }^{\circ} \mathrm{C}$, considering a completely randomized design in a factorial arrangement $(5 \times 4)$ with four replicates. The first count of radicle emission and germination, final radicle emission, seed germination, radicle emission rate index, mean radicle emission time, and seedling dry mass were measured. Germination process of eggplant seeds was completely inhibited at $41^{\circ} \mathrm{C}$, and the optimal temperature for seed germination is $25^{\circ} \mathrm{C}$. Calcium nitrate priming potentiates the seed germination process, resulting in higher radicle emission rate index and higher germination rate. Low temperature $\left(15^{\circ} \mathrm{C}\right)$ has greater interference in the germination rate of eggplant seeds when compared to high temperature $\left(35^{\circ} \mathrm{C}\right)$.
\end{abstract}

Keywords: chemical agents, physiological potential, Solanum melongena L., temperature

\section{Introduction}

Eggplant (Solanum melongena L.) originally from India, is an annual vegetable of the Solanaceae family. Consumption of $S$. melongena has been widely widespread due to its medicinal benefits, such as cholesterol reduction (Antonini et al., 2002). National and world seed production has increased in recent years due to the large consumption of vegetables. This higher demand for vegetable seeds requires that they have quality and vigor, and to ensure the optimal development of the seedlings, physiological priming is a technique used (Medeiros et al., 2015).

Abiotic stresses may affect seed performance either by favoring, delaying, or inhibiting their germination after sowing (Nascimento \& Lima, 2008). Several techniques can be used to promote greater seed tolerance to the abiotic stresses, especially thermal and water stresses. These techniques include the physiological priming of the seeds, which promotes greater germination capacity and seedling emergence and thus ensure greater uniformity of the plant stand under adverse environmental conditions (Bisognin et al., 2016).

Seed priming is a pre-sowing treatment which leads to a physiological potential that enables the seed to germinate more efficiently. Priming reduces germination time, improves emergence uniformity and vigor of seedlings. The controlled hydration of the seeds can be accomplished by hydropriming or through osmotic solutions (Pinedo \& Ferraz, 2008).

The osmopriming consists in controlling the hydration level of the seeds during the imbibition phase, which is commonly performed with a solution containing substances or chemical agents such as polyethylene glycol (PEG), calcium nitrate, potassium nitrate, among others. Osmopriming allows hydration until seed and solution water potentials reach equilibrium, and the biochemical preparatory process for germination is activated (Marcos Filho, 2015). 
In eggplant seeds, the osmopriming with potassium nitrate solution improved the germination rate when exposed to low temperatures (Nascimento \& Lima, 2008). The calcium nitrate solution can also be used in seed pretreatment to improve the germination process and act to overcome dormancy in some seeds (Silva et al., 2017). For example, in Brachiaria seeds, the dormancy is related to several factors, especially physical properties, and the priming with calcium nitrate resulted in higher tolerance of Brachiaria brizantha seeds to high humidity and high-temperature stress (Batista et al., 2016), thus being efficient in overcoming dormancy.

The priming of tomato seeds with $\mathrm{CaCl}_{2}$ and $\mathrm{KNO}_{3}$ solution was efficient to improve the seedling growth under salinity conditions (Ebrahimi et al., 2014). Similarly, Batista et al. (2015) reported that the priming with $\mathrm{KNO}_{3}$ and $\mathrm{Ca}\left(\mathrm{NO}_{3}\right)_{2}$ resulted in greater growth of pepper (C. frutescens) seedlings. However, the priming of cucumber seeds with potassium nitrate showed little effect in improving the germination and growth rate of seedlings under salt stress conditions (Oliveira \& Steiner, 2017).

There are few studies with the use of the amino acid phenylalanine for the priming of seeds. The beneficial effect of this amino acid application on seed germination is due to the biochemical and structural mechanisms of resistance in plants, favoring adaptation to adverse environmental conditions (Stangarlin et al., 2011). However, in the study performed by Gouveia et al. (2017), the priming of corn seeds with calcium nitrate and phenylalanine promoted greater germination rate of low vigor seeds.

The production of pepper seeds with high physiological quality has been pointed out with one of the main challenges for seed producers. Thus, the objective of this study was to evaluate the physiological potential of eggplant seeds primed with different chemical agents and exposed to adverse temperature.

\section{Material and Methods}

The experiment was carried out in the Laboratory of Seed Analysis and Plant Physiology of the State University of Mato Grosso do Sul (UEMS), in Cassilândia, MS, Brazil, during the year 2018. For the research, eggplant seeds (Solanum melongena L.) without previous treatment were used.

The treatments were arranged in a completely randomized design in a $4 \times 5$ factorial scheme: four stress treatment by adverse temperatures [optimal temperature at $25^{\circ} \mathrm{C}$ (control), low temperature stress at $15{ }^{\circ} \mathrm{C}$, high temperature stress at $35{ }^{\circ} \mathrm{C}$, and extreme temperature stress at $41{ }^{\circ} \mathrm{C}$ ] and five chemical agents used in seed priming [unprimed (control); water (hydropriming); calcium nitrate $\left(\mathrm{Ca}\left(\mathrm{NO}_{3}\right)_{2}\right)$ at $0.2 \%$; amino acid L-phenylalanine at $0.05 \%$; calcium nitrate $\left(\mathrm{Ca}\left(\mathrm{NO}_{3}\right)_{2}\right)$ at $0.2 \%+\mathrm{L}$-phenylalanine at $0.05 \%$, with four replicates of 50 seeds.

Seeds were submitted to priming by direct immersion in different chemical solutions for $24 \mathrm{~h}$ at $25^{\circ} \mathrm{C}$, with a photoperiod of $12{ }^{\circ} \mathrm{C}$. The solution was aerated from $2 \mathrm{~h}$ after the beginning of seed imbibition. After priming, seeds were removed and washed with tap water, and then put to dry at room temperature for $5 \mathrm{~h}$, until the seed water content reduces to the initial value. The water content of the seeds was measured by the oven drying method at $130-133{ }^{\circ} \mathrm{C}$, for $24 \mathrm{~h}$ (MAPA, 2009), obtaining initial water content (before priming) and final water content (after priming). The initial water content was $6.6 \%$, and after the priming period, the final water content of $51.48 \%$.

Germination test: four replicates of 50 seeds were distributed among two sheets of paper towel moistened with distilled water at the proportion of 3.0 times the mass of dry paper. The paper towel sheets were turned into rolls, and then the germination was carried out in growth chambers, under a $12 \mathrm{~h}$ photoperiod and at different adverse temperatures $\left(15,25,35\right.$, and $\left.41^{\circ} \mathrm{C}\right)$.

During the seed germination process, the following characteristics were measured:

The first count of germination test ( 7 days) and seed germination percentage (14 days): Consisted of four subsamples of 50 seeds per treatment, and the results were expressed as a percentage of normal seedlings (MAPA, 2009);

The first count of radicle emission (7 days) and final radicle emission percentage (14 days): four subsamples of 50 seeds per treatment were used, and the results were expressed as a percentage of seeds with radicle;

Radicle emission rate index (RERI) and germination rate index (GRI): conducted in conjunction with the seed germination test, and calculated according to the equation below proposed by Maguire (1962).

$$
\text { RERI or GRI }=G 1 / T 1+G 2 / T 2+\ldots+G i / T i
$$

Where, $G i=$ Number of radicles emitted or number of germinated seeds on a given day; $T i=$ Time in days from the sowing day (0). 
Mean radicle emission time (MRET) or mean germination time (MGT): conducted in conjunction with the seed germination test, and calculated according to the equation below proposed by Labouriau (1983).

$$
\text { MRET or } M G T=(\Sigma N i T i) /(\Sigma N i)
$$

Where, $N i=$ Number of radicles emitted or number of germinated seeds germination on a given day; $T i=$ Time in days from the sowing day (0).

The total dry mass of seedlings (TDM): Four replicates of 20 seedlings per treatment were used, and the total dry mass was determined after oven drying at $65^{\circ} \mathrm{C}$ for $72 \mathrm{~h}$. Values were expressed as mg seedling ${ }^{-1}$.

Statistical analysis: The data were previously transformed into $\arcsin (x)^{0.5}$, and then data were submitted to analysis of variance, and means were grouped by the Scott-Knott test at the 5\% probability level.

\section{Results and Discussion}

The stress caused by the extremely high temperature $\left(41^{\circ} \mathrm{C}\right)$ completely inhibited the seed germination, regardless of the priming treatments. It indicates that this temperature was very detrimental to the germination process of eggplant seeds (Solanum melongena L.). Therefore, since it was not possible to collect data in this extreme temperature condition, this abiotic stress treatment was not used in the statistical analyses. Thus, only the other temperature conditions (i.e., 15,25 , and $35^{\circ} \mathrm{C}$ ) were compared by the statistical analysis.

The seeds presented initial water content of $6.6 \%$ and after the priming reached the final water content of $51.48 \%$. The initial water content was relatively low because the seeds were commercially purchased from packages, and after priming from the direct immersion for $24 \mathrm{~h}$, there was a significant increase in the seed water content. The germination process has a direct influence on the water content of the seeds, such as the reorganization of cell membranes, biosynthesis of new enzymes, and ribonucleic acid $\left(\mathrm{RNA}_{\mathrm{m}}\right)$, among other processes.

Analysis of variance reported that the effect of adverse temperature stress was significant on all seed germination and seedling growth traits, while the effect of seed priming methods was significant on the first count of radicle emission, final radicle emission, radicle emission rate index (RERI), and first count of germination test. Interaction between adverse temperature stress and seed priming methods showed no significant effect for any of the traits measured (Tables 1 and 2).

About the germination process, the exposure of eggplant seeds to low-temperature stress resulted in a lower percentage of seeds with radicle emission in the first count (7 days) and the final count (14 days). Low temperature also caused a lower radicle emission rate index (RERI) and higher mean radicle emission time (MRET) when compared to the other temperature stresses. The temperature of $25{ }^{\circ} \mathrm{C}$ resulted in the highest germination rate and was the optimal temperature for the eggplant germination process (Table 1).

Table 1. First count of radicle emission (7 days), final radicle emission (14 days), radicle emission rate index (RERI) and mean radicle emission time (MRET) according to the stress treatment by adverse temperature and priming with different chemical agents of eggplant seeds (Solanum melongena L.). Cassilândia, MS, Brazil, 2018

\begin{tabular}{lllll}
\hline \multirow{2}{*}{ Stress by Adverse Temperatures } & \multicolumn{2}{c}{ Radicle Emission } & \multirow{2}{*}{ RERI } & \multirow{2}{*}{ MRET (Days) } \\
\cline { 2 - 5 } & Fist Count (7 Days) & Final (14 Days) & & \\
\hline $15{ }^{\circ} \mathrm{C}($ low) & $0 \mathrm{c}$ & $32 \mathrm{c}$ & $1.56 \mathrm{c}$ & $11.51 \mathrm{a}$ \\
$25^{\circ} \mathrm{C}($ optimal) & $93 \mathrm{a}$ & $96 \mathrm{a}$ & $9.43 \mathrm{a}$ & $5.15 \mathrm{c}$ \\
$35^{\circ} \mathrm{C}$ (high) & $62 \mathrm{~b}$ & $71 \mathrm{~b}$ & $6.61 \mathrm{~b}$ & $5.83 \mathrm{~b}$ \\
\hline \multirow{2}{*}{ Seed Priming } & \multicolumn{4}{c}{ Radicle Emission } \\
\cline { 2 - 5 } & Fist Count (7 Days) & Final (14 Days) & RER & \multirow{2}{*}{ MRET (Days) } \\
\hline Unprimed seeds (control) & $41 \mathrm{~b}$ & $54 \mathrm{~b}$ & $4.64 \mathrm{~b}$ & $8.12 \mathrm{a}$ \\
Water (hydropriming) & $52 \mathrm{a}$ & $62 \mathrm{~b}$ & $5.65 \mathrm{~b}$ & $7.62 \mathrm{a}$ \\
Calcium nitrate & $58 \mathrm{a}$ & $76 \mathrm{a}$ & $6.68 \mathrm{a}$ & $6.86 \mathrm{a}$ \\
L-phenylalanine & $54 \mathrm{a}$ & $68 \mathrm{a}$ & $6.00 \mathrm{a}$ & $7.46 \mathrm{a}$ \\
Calcium nitrate + L-phenylalanine & $56 \mathrm{a}$ & $72 \mathrm{a}$ & $6.36 \mathrm{a}$ & $7.42 \mathrm{a}$ \\
\hline CV (\%) & 18.19 & 22.09 & 17.25 & 6.86 \\
\hline
\end{tabular}

Note. Means followed by different letters in the column shows significant differences by the Scott-Knott test, at the $5 \%$ probability level. $\mathrm{CV}=$ coefficient of variation. 
The osmopriming with different chemical agents improved the first count of radicle emission, final radicle emission, and radicle emission rate index; however, there was no difference between the chemical agents used (Table 1). Priming promotes the reorganization of cell membranes, especially mitochondria, which are essential for the cellular respiration process. Thus, after the reorganizations of cell membranes, the germination process of the seeds occurs faster.

The seed priming has been shown to have a beneficial effect on germination and growth rate of vegetable crops. Osmopriming of eggplant seeds provided a higher germination rate and seedling emergence rate index (Fanan \& Novembre, 2007). Reis et al. (2012) also reported that $\mathrm{KNO}_{3}$ priming resulted in higher germination rate and lower mean germination time in eggplant cv. Embu.

Similarly, to the radicle emission pattern, low-temperature stress $\left(15^{\circ} \mathrm{C}\right)$ was also unsuitable for the normal seedling formations (Table 2), together with high-temperature stress at $35{ }^{\circ} \mathrm{C}$, while the temperature of $25{ }^{\circ} \mathrm{C}$ was the most suitable for the germination process.

At the first count of normal seedlings (at 7 days), the temperature at $25{ }^{\circ} \mathrm{C}$ had approximately $42 \%$ of normal seedlings, while exposure to high temperature $\left(35^{\circ} \mathrm{C}\right)$ was only $6.30 \%$, and at low temperature $\left(15^{\circ} \mathrm{C}\right)$ still had no normal seedlings.

The germination process involves a series of metabolic activities, and these reactions have specific requirements regarding temperature, mainly because these reactions are related to enzymatic systems. In these cases, temperature changes can affect the speed, uniformity and the germination rate of the seeds, and for most cultivated species the optimum temperature is between 20 and $30^{\circ} \mathrm{C}$ (Marcos Filho, 2015).

In the first count of normal seedlings, the temperature of $15^{\circ} \mathrm{C}$ did not result in normal seedlings, because low-temperature conditions can reduce the speed of imbibition and mobilization of seed reserves, delaying the germination process and reducing seedling growth (Marcos Filho, 2015).

At the final count of germination test under $25{ }^{\circ} \mathrm{C}$, more than $90 \%$ of the seeds formed normal seedlings, whereas the temperature of $35{ }^{\circ} \mathrm{C}$ was almost $50 \%$, and the temperature of $15{ }^{\circ} \mathrm{C}$ had less than $2 \%$ of normal seedlings. The normal seedlings under the different temperature stress conditions did not differ about the total dry mass of the eggplant seedlings at 25 and $35^{\circ} \mathrm{C}$. However, lower growth was observed at $15^{\circ} \mathrm{C}$ (Table 2).

Table 2. First count of germination test ( 7 days), final seed germination (14 days), total dry mass of seedlings (TDM) according to the stress treatment by adverse temperatures and priming with different chemical agents of eggplant seeds (Solanum melongena L.). Cassilândia, MS, Brazil, 2018

\begin{tabular}{|c|c|c|c|}
\hline \multirow{2}{*}{ Stress by Adverse Temperatures } & \multicolumn{2}{|c|}{ Germination } & \multirow{2}{*}{ TDM (mg) } \\
\hline & Fist Count (7 days) & Final (14 days) & \\
\hline $15^{\circ} \mathrm{C}$ (low) & $0 \mathrm{c}$ & $2 \mathrm{c}$ & $8.85 \mathrm{~b}$ \\
\hline $25^{\circ} \mathrm{C}$ (optimal) & $41 \mathrm{a}$ & $90 \mathrm{a}$ & $84.82 \mathrm{a}$ \\
\hline $35^{\circ} \mathrm{C}$ (high) & $6 \mathrm{~b}$ & $48 \mathrm{~b}$ & $73.56 \mathrm{a}$ \\
\hline \multirow{2}{*}{ Seed Priming } & \multicolumn{2}{|c|}{ Germination } & TDM (m ) \\
\hline & Fist Count (7 days) & Final (14 days) & IDMi (mg) \\
\hline Unprimed seeds (Control) & $11 \mathrm{~b}$ & $41 \mathrm{a}$ & $50.00 \mathrm{a}$ \\
\hline Water (hydropriming) & $17 \mathrm{~b}$ & $49 \mathrm{a}$ & $54.69 \mathrm{a}$ \\
\hline Calcium nitrate & $20 \mathrm{a}$ & $49 \mathrm{a}$ & $67.06 \mathrm{a}$ \\
\hline L-phenylalanine & $12 \mathrm{~b}$ & $48 \mathrm{a}$ & $52.79 \mathrm{a}$ \\
\hline Calcium nitrate + L-phenylalanine & $20 \mathrm{a}$ & $46 \mathrm{a}$ & $54.17 \mathrm{a}$ \\
\hline $\mathrm{CV}(\%)$ & 41.10 & 22.38 & 29.80 \\
\hline
\end{tabular}

Note. Means followed by different letters in the column shows significant differences by the Scott-Knott test, at the $5 \%$ probability level. $\mathrm{CV}=$ coefficient of variation.

The priming with calcium nitrate promoted a higher germination percentage in the first count. These results indicate that the seed priming with calcium nitrate solution was capable of promoting greater expression of pre-existing seed vigor, resulting in a higher germination rate at 7 days after sowing (DAS). However, at 14 DAS, there was stabilization between the seed priming treatments (Table 2). Nascimento (2005) also reported that osmopriming with $\mathrm{KNO}_{3}$ solution resulted in higher germination percentage of eggplant seeds under 
low-temperature abiotic stress conditions. The calcium nitrate solution showed to be more efficient for the germination process since the application of the antioxidant alone resulted in germination performance similar to the unprimed seeds and hydropriming. However, when the antioxidant was associated with calcium nitrate promoted a result similar to priming with calcium nitrate alone, emphasizing the efficiency of chemical agent in the osmopriming of eggplant seeds.

Nitrate stimulates the pentose phosphate pathway connected with the glycolytic pathway, responsible by the supply of free energy in the form of ATP and carbon skeleton that are used to the embryonic axis growth. In this case, the priming with the calcium nitrate favored radicle emission and promoted a higher germination percentage in the first count.

The efficiency of calcium nitrate in seed priming was also reported by Gouveia et al. (2017) when evaluating the physiological potential of maize seeds primed with different chemical agents and submitted to abiotic stress, in which the calcium nitrate priming resulted in greater germination and emergence of seedlings in sub-optimal temperature conditions when compared to the priming with water and amino acid phenylalanine.

Similarly, Batista et al. (2015) when evaluating the quality of pepper seedlings resulting from priming with water, potassium nitrate $(0.2 \%)$, calcium nitrate $(0.2 \%), \mathrm{GA}_{3}$ gibberellin $\left(200 \mathrm{mg} \mathrm{L}^{-1}\right)$ and antioxidant riboflavin $(25 \mathrm{mg}$ $\left.\mathrm{L}^{-1}\right)$, observed that the priming with $\mathrm{KNO}_{3}$ and $\mathrm{Ca}\left(\mathrm{NO}_{3}\right)_{2}$ resulted in higher dry matter of $C$. frutescens seedlings.

Thus, physiological priming consists of a set of techniques that aim to express all the physiological potential of the seed lot (Marcos Filho, 2015), which was observed in the initial evaluations of seed germination. In the first count evaluations, both for radicle emission and for normal seedlings, the germination occurred more rapidly in the seeds primed with calcium nitrate. These results show that priming improved the expression of higher seed performance.

\section{Conclusions}

The priming of eggplant seeds with calcium nitrate solution and antioxidant L-phenylalanine either alone or in combination promotes greater expression of the physiological potential of the seeds, resulting in greater germination rate.

Low temperature $\left(15^{\circ} \mathrm{C}\right)$ results in a lower radicle emission rate and lower formation of normal seedlings when compared to high temperature $\left(35^{\circ} \mathrm{C}\right)$. The optimal temperature for the seed germination process is $25^{\circ} \mathrm{C}$, while the germination process of eggplant seeds is completely inhibited at $41^{\circ} \mathrm{C}$.

\section{Acknowledgements}

This study was financed in part by the Coordenação de Aperfeiçoamento de Pessoal de Nível Superior-Brasil (CAPES)-Finance Code 001.

\section{References}

Antonini, A. C. C., Robles, W. G. R., Tessarioli Neto, J., \& Kluge, R. A. (2002) Capacidade produtiva de cultivares de berinjela. Horticultura Brasileira, 20(4), 646-648. https://doi.org/10.1590/S0102-05362002 000400027

Batista, T. B., Binotti, F. F. S., Cardoso, E. D., Bardiviesso, E. M., \& Costa, E. (2015). Aspectos fisiológicos e qualidade de mudas da pimenteira em resposta ao vigor e condicionamento das sementes. Bragantia, 74(4), 367-373. https://doi.org/10.1590/1678-4499.0133

Batista. T. B., Cardoso. E. D., Binotti. F. F. S., Costa. E., \& Sá, M. E. (2016). Priming and stress under high humidity and temperature on the physiological quality of Brachiaria brizantha cv. MG-5 seeds. Acta Scientiarum, 38(1), 123-127. https://doi.org/10.4025/actasciagron.v38i1.26021

Bisognin, M. B., Kulczynski, S. M., Ferrari, M., Gaviraghi, R., Pelegrin, A. J., \& Souza, V. Q. (2016). Desempenho fisiológico de sementes olerícolas em diferentes tempos de hidrocondicionamento. Revista de Ciências Agrárias, 39(3), 349-359. https://doi.org/10.19084/RCA15163

Labouriau, L. G. (1983). A germinação das sementes (p. 174). Washington: Secretaria geral da Organização dos Estados Americanos.

MAPA (Ministério da Agricultura, Pecuária e Abastecimento). (2009). Regras para análise de sementes (p. 399). Brasília: MAPA/ACS. 
Ebrahimi, R., Ahmadizadeh, M., \& Rahbarian, P. (2014). Enhancing stand establishment of tomato cultivars under salt stress condition. Journal Horticulture, Biology and Environment, 5(1), 19-42. https://doi.org/ $10.1007 / \mathrm{s} 13580-014-0032-7$

Fanan, S., \& Novembre, A. D. L. C. (2007). Condicionamento fisiológico de sementes de berinjela. Bragantia, 66(4), 675-683. https://doi.org/10.1590/S0006-87052007000400018

Gouveia, G. C. C., Binotti, F. F. S., \& Costa, E. (2017). Priming effect on the physiological potential of maize seeds under abiotic stress. Pesquisa Agropecuária Tropical, 47(3), 328-335. https://doi.org/10.1590/ 1983-40632016v4746560

Maguire, J. D. (1962). Speed of germination-aid in selection and evaluation for seedling and vigour. Crop Science, 2, 176-177. https://doi.org/10.2135/cropsci1962.0011183X000200020033x

Marcos Filho, J. (2015). Fisiologia de sementes de plantas cultivadas (p. 659). Londrina: ABRATES.

Medeiros, M. A., Torres, S. B., Negreiros, M. Z., \& Madalena, J. A. S. (2015). Hidrocondicionamento e armazenamento de sementes de melão. Semina: Ciências Agrárias, 36(1), 57-66. https://doi.org/10.5433/ $1679-0359.2015 \mathrm{v} 36 \mathrm{n} 1 \mathrm{p} 57$

Nascimento, W. M. (2005). Condicionamento osmótico de sementes de hortaliças visando a germinação em condições de temperaturas baixas. Horticultura Brasileira, 23(2), 211-214. https://doi.org/10.1590/ S0102-05362005000200010

Nascimento, W. M., \& Lima, L. B. (2008). Condicionamento osmótico de sementes de berinjela visando a germinação sob temperaturas baixas. Revista Brasileira de Sementes, 30(2), 224-227. https://doi.org/ $10.1590 / \mathrm{S} 0101-31222008000200029$

Oliveira, C. E. S., \& Steiner, F. (2017). Potassium nitrate priming to mitigate the salt stress on cucumber seedlings. Scientia Agrararia Paranaensis, 16(4), 454-462.

Pinedo, G. J. V., \& Ferraz, I. D. K. (2008). Hidrocondicionamento de Parkia pendula [Benth ex Walp]: sementes com dormência física de árvore da Amazônia. Revista Árvore, 32(1), 23-38. https://doi.org/10.1590/ S0100-67622008000100006

Reis, R. G. E., Guimaraes, R. M., Vieira, A. R., Gonçalves, N. R., \& Costa, V. H. (2012). Physiological quality of osmoprimed eggplant seeds. Ciência e Agrotecnologia, 36(5), 526-532. https://doi.org/10.1590/ S1413-70542012000500005

Silva, A. G., Paula, R. C. M., Binotti, F. F. S., \& Costa, E. (2017). Comportamento germinativo de sementes de eucalipto em duas temperaturas com o uso de sais inorgânicos. Enciclopédia Biosfera, 14(25), 358-364. https://doi.org/10.18677/EnciBio_2017A33

Stangarlin. J. R., Kuhn. O. J., Toledo. M. V., Portz. R. L., Schwan-Estrada. K. R. F., \& Pascholati. S. F. (2011). A defesa vegetal contra fitopatógenos. Scientia Agraria Paranaenis, 10, 18-46.

\section{Copyrights}

Copyright for this article is retained by the author(s), with first publication rights granted to the journal.

This is an open-access article distributed under the terms and conditions of the Creative Commons Attribution license (http://creativecommons.org/licenses/by/4.0/). 